\title{
THE OXIDASE REACTION IN THE CLASSIFICATION OF THE MICROCOCCACEAE
}

\author{
P. A. Boswell* $\dagger$, G. F. Batstone $\dagger$ AND R. G. Mitchell $\ddagger$ \\ Departments of Pathology, Royal Infirmary, Bristol $2 \dagger$ and the \\ Churchill Hospital, Headington, Oxford $\ddagger$
}

STEEL (1962) tested the oxidase reactions of the Micrococcaceae, using strains from the National Collection of Type Cultures classified by the system of Shaw, Stitt and Cowan (1951). He observed that strains that gave a positive reaction by Kovács' (1956) method were in general those that oxidised glucose. Baird-Parker $(1963,1965)$ devised a system of classification in which staphylococci and micrococci were differentiated by their mode of glucose metabolism and could be assigned to various subgroups according to the results of a small number of biochemical tests. We have examined a large number of strains from various sources and related their oxidase reactions to their Baird-Parker subgroups.

\section{MATERIALS AND METHODS}

From the following sources we obtained 767 strains of staphylococci and micrococci: (1) routine pathological specimens received in the laboratories of the United Oxford Hospitals and the United Bristol Hospitals; (2) "settle" plates exposed inside or outside hospital; (3) normal human skin; (4) reference strains supplied by Dr A. C. Baird-Parker; (5) farm and zoo animals in Denmark (Alder, Gillespie, Mitchell and Rosendal, unpublished); (6) the Czechoslovak Collection of Micro-organisms $\{11$ strains assigned to group 1, subgroup 1a, and four strains assigned to group 2, subgroup 2a, by Rosypal, Rosypalová and Hořejš (1966)\}; (7) the National Collection of Type Cultures (four strains).

The strains were classified by the methods of Baird-Parker. No distinction was made between Staphylococcus subgroups II and V (Pennock and Huddy, 1967). Micrococcus subgroup 7 strains were divided into white strains sensitive to paromomycin and yellow strains resistant to paromomycin (Lacey and Boswell, 1968).

After overnight growth on nutrient agar at $37^{\circ} \mathrm{C}$ (or 3 days at room temperature in the case of Micrococcus subgroup 8 strains), the organisms were tested for oxidase activity by Steel's modification of Kovács' method. Strains producing a purple colour within $60 \mathrm{~s}$ were recorded as positive.

\section{RESUlTS AND DISCUSSION}

The oxidase reactions of the strains are shown in the table. All the oxidase-positive strains that were retested after repeated subculture retained their positive reaction. Steel (1962) considered that strains that gave a positive oxidase reaction were in general those that oxidised glucose, and this was confirmed in the present study. All strains of Staphylococcus aureus and coagulase-negative subgroups of staphylococci tested were oxidase negative.

Amongst the micrococci many strains of subgroups 5 and 6 were oxidase positive. Members of both of these subgroups are derived mainly from animal sources. The strains from the Czechoslovak Collection of Micro-organisms assigned by Rosypal et al. (1960) to their group 2, subgroup 2a were oxidase negative. These yellow-pigmented strains oxidised glucose and were placed in Micrococcus subgroup 5 on their biochemical reactions, but were found to be relatively sensitive to novobiocin, differing in this from most glucose-oxidising strains, and resembling yellow-pigmented Micrococcus subgroup 7 strains (Mitchell and

Received 20 July 1971; accepted 24 Aug 1971.

* Present address: Department of Bacteriology, St Bartholomew's Hospital, London, E.C.1

J. MED. MICROBIOL.-VOL. 5 (1972) 
Baird-Parker, 1967; Jeffries, 1968; Lacey and Boswell, 1968). When tested against paromomycin by a plate method they were however sensitive to $0.5 \mu \mathrm{g}$ per ml, unlike yellowpigmented Micrococcus subgroup 7 strains which were resistant to $>2 \mu \mathrm{g}$ per $\mathrm{ml}$. All the yellow-pigmented Micrococcus subgroup 7 strains were oxidase positive, as were the majority but not all of the white-pigmented Micrococcus subgroup 7 strains. All strains from the Czechoslovak Collection of Micro-organisms which were assigned to group 1, subgroup 1a of Rosypal et al. (1966) and NCTC 7011 and 7743 were classified as yellow strains of BairdParker's Micrococcus subgroup 7; NCTC no. 7520 and no. 7523 were placed in Micrococcus subgroup 8.

TABLE

The oxidase reactions of staphylococci and micrococci classified according to Baird-Parker

\begin{tabular}{|c|c|c|c|c|c|c|c|c|c|c|c|c|c|c|}
\hline \multirow{3}{*}{$\begin{array}{l}\text { Oxidase } \\
\text { reaction }\end{array}$} & \multicolumn{14}{|c|}{ Number of strains belonging to } \\
\hline & \multicolumn{5}{|c|}{ Staphylococcus subgroup } & \multicolumn{9}{|c|}{ Micrococcus subgroup } \\
\hline & $\mathbf{I}$ & $\mathrm{II}^{*}$ & III & IV & VI & 1 & 2 & 3 & 4 & 5 & 6 & $\begin{array}{c}7 \\
\text { white }\end{array}$ & $\begin{array}{c}7 \\
\text { yellow }\end{array}$ & 8 \\
\hline Positive & 0 & 0 & 0 & 0 & $\mathbf{0}$ & 1 & 3 & 3 & 0 & 74 & 16 & 6 & 60 & 4 \\
\hline Negative & 104 & 136 & 5 & 12 & 64 & 6 & 18 & 120 & 5 & 92 & 34 & 2 & 0 & 2 \\
\hline No. of strains tested & 104 & 136 & 5 & 12 & 64 & 7 & 21 & 123 & 5 & 166 & 50 & 8 & 60 & 6 \\
\hline
\end{tabular}

* Includes Staphylococcus subgroup V.

The observation that all strains of Staph. aureus were oxidase negative, whereas yellowpigmented strains of Micrococcus subgroup 7 were oxidase positive, provides a rapid laboratory screening test for yellow-pigmented strains of the Micrococcaceae. Oxidase-positive strains are micrococci and unlikely to be pathogenic. Oxidase-negative strains, however, still need further investigation.

\section{SUMMARY}

On examining the oxidase reactions of 767 strains of staphylococci and micrococci, it was found that positive reactions were confined to Baird-Parker's Micrococcus group. All yellowpigmented Micrococcus subgroup 7 strains were oxidase positive, and this provides a rapid distinction between these and strains of Staphylococcus aureus.

We thank Dr A. C. Baird-Parker and L. Jeffries Esq. for providing strains, Dr V. G. Alder for his advice and Professor F. W. O'Grady for his criticisms of the manuscript.

\section{REFERENCES}

BaIRd-PARKer, A. C. 1963. A classification of micrococci and staphylococci based on physiological and biochemical tests. J. Gen. Microbiol., 30, 409.

BAIRD-PARKer, A. C. 1965 . The classification of staphylococci and micrococci from worldwide sources. J. Gen. Microbiol., 38, 363.

JefFrIES, L. 1968. Sensitivity to novobiocin and lysozyme in the classification of Micrococcaceae. J. Appl. Bact., 31, 436. 
Kovács, N. 1956. Identification of Pseudomonas pyocyanea by the oxidase reaction. Nature, Lond., 178, 703.

LACEY, R. W., AND Boswell, P. A. 1968. Resistance to paromomycin, bacitracin and novobiocin in the Micrococcaceae. J. Appl. Bact., 31, 302.

Mrtchell, R. G., AND BAIRD-PARKeR, A. C. 1967. Novobiocin resistance and the classification of staphylococci and micrococci. J. Appl. Bact., 30, 251.

Pennock, C. A., AND Huddy, R. B. 1967. Phosphatase reaction of coagulase-negative staphylococci and micrococci. J. Path. Bact., 93, 685.

Rosypal, S., Rosypalová, Alena, AND HoŘejš, J. 1966. The classification of micrococci and staphylococci based on their DNA base composition and Adansonian analysis. J. Gen. Microbiol., 44, 281.

Shaw, Constance, Stitt, Jennifer M., and Cowan, S. T. 1951. Staphylococci and their classification. J. Gen. Microbiol., 5, 1010.

STEEL, K. J. 1962. The oxidase activity of staphylococci. J. Appl. Bact., 25, 445. 